\title{
Overexpression of Two Upstream Phospholipid Signaling Genes Improves Cold Stress Response and Hypoxia Tolerance, but Leads to Developmental Abnormalities in Barley
}

\author{
Krisztián Gierczik ${ }^{1,2} \cdot$ András Székely $^{1} \cdot$ Mohamed Ahres $^{1,2} \cdot$ Zsuzsa Marozsán-Tóth $^{1} \cdot$ Ildikó Vashegyi ${ }^{1}$. \\ Wendy Harwood ${ }^{3} \cdot$ Balázs Tóth $^{1} \cdot$ Gábor Galiba $^{1,2} \cdot$ Alexandra Soltész $^{1} \cdot$ Attila Vágújfalvi $^{1}$
}

Published online: 22 July 2019

(C) The Author(s) 2019

\begin{abstract}
Phosphatidylinositol transfer protein (PITP) and phosphatidylinositol 4-kinase (PI4K) are very upstream regulatory elements of the phospholipid signaling pathway in the signal transduction network. Unlike in animal systems, their role in stress signaling is poorly understood in plants. To study this area, PITP- and PI4K-overexpressing transgenic barley lines were developed. Morphological and developmental abnormalities were surveyed and characterized. It was revealed that the overexpression of the upstream signaling genes led to more phenotypic abnormalities than in other transgenic studies working with effector genes or even transcription factors. We hypothesize that this high level of abnormalities is the consequence of the modulation of the very upstream signal transduction pathway elements. On the other hand, we also revealed that overexpression of the PITP and PI4K genes increased stress tolerance during hypoxic cold stress, but not during salinity stress. Differences were also found in the level of frost tolerance between the transgenic overexpression plants and the recipient Golden Promise line. Molecular analysis showed that this improvement was not related to the most important cold responsive transcription factors, the $C B F$ genes. We conclude that the transgenic method may be useful to prove the role of an upstream signaling element; however, due to the many developmental consequences that occur as side effects, it is a less advisable approach to achieve improved stress tolerance.
\end{abstract}

Keywords Phosphatidylinositol transfer protein $\cdot$ Phosphatidylinositol 4-kinase $\cdot$ Signal transduction $\cdot$ Abiotic stress tolerance . Morphogenetic disorders

\section{Introduction}

Like any living creature, plants often face environmental extremes, many of these being life-threatening biotic or abiotic

Alexandra Soltész and Attila Vágújfalvi contributed equally to this work.

Electronic supplementary material The online version of this article (https://doi.org/10.1007/s11105-019-01154-5) contains supplementary material, which is available to authorized users.

Alexandra Soltész

soltesz.alexandra@agrar.mta.hu

Attila Vágújfalvi

vagujfalvi.attila@agrar.mta.hu

1 Agricultural Institute, Centre for Agricultural Research, Hungarian Academy of Sciences, Martonvásár 2462, Hungary

2 Festetics Doctoral School, Georgikon Faculty, University of Pannonia, Keszthely 8360, Hungary

3 John Innes Centre, Norwich Research Park, Norwich NR4 7UH, UK stresses. However, being sessile organisms, plants are unable to escape, so, in many case, their survival depends on the ability to cope and respond appropriately to the received signals in situ. The complexity and diversity of the signaling pathways allow them to react with fine-tuned, adequate responses. It has long been well documented that $\mathrm{Ca}^{2+}$ plays a crucial role in cellular signaling, not just in animal cells but in the plant cells as well. It is one of the most important secondary messenger molecules which regulate many essential physiological processes. Elevated cytosolic $\mathrm{Ca}^{2+}$ concentration initiates several signal transduction pathways in plants in response to abiotic stresses, such as salt, cold, osmotic stress, or anoxia (reviewed by Lindberg et al. 2012 and Ranty et al. 2016). One of those pathways in which $\mathrm{Ca}^{2+}$ is a crucial component is the socalled phosphoinositide signaling pathway, named after the very first signaling molecule, phosphoinositol, which is, as yet, poorly characterized in plant cells.

Besides being structural components of biological membranes, phosphoinositides are involved in intracellular signaling 
across plasma membranes. They are precursors of second messengers and act as ion channel activators (Xue et al. 2009), thus regulating cellular responses to environmental changes, among which are abiotic stresses (Xue et al. 2007). Phosphatidylinositol (PI) is the first molecule of the phosphoinositide signaling pathway. PI-specific lipid transfer protein (PITP) transports the PI between membranes, whereas PI 4-kinase (PI4K) catalyzes the phosphorylation of the PI molecule to PI 4-phosphate (PI4P), which can be further phosphorylated to PI 4, 5-bisphosphate $\left(\mathrm{PIP}_{2}\right)$. The membrane-bound phospholipase C (PLC) enzyme catalyzes the hydrolysis of $\mathrm{PIP}_{2}$ producing secondary messenger molecules: diacylglycerol (DAG) and inositol 1, 4, 5triphosphate $\left(\mathrm{IP}_{3}\right)$. DAG activates ion channels and protein kinases to generate phosphatidic acid, a typical plant second messenger molecule, whereas $\mathrm{IP}_{3}$ activates receptors on the endoplasmic reticulum membrane, which release $\mathrm{Ca}^{2+}$ into the cytoplasm. The phosphoinositide signaling pathway is excellently reviewed recently by Delage et al. (2013), Ruelland et al. (2015), and Hou et al. (2016); however, it should be noted that the exact function of each and every element is not fully understood yet in plant systems.

Although novel molecular techniques are now available, such as genome editing especially using CRISPR-based methods (Ricroch et al. 2017), overexpression or silencing the gene of interest by transformation methods has proved to be a very useful technique in gene functional analysis research for a long time. To prove the role of genes in plant development or in stress tolerance, transcription factors, but also effector genes, have been examined (reviewed by Zhang 2003 and Haak et al. 2017). However, it is less common to determine the role of a gene involved in the signaling pathway using plant transformation techniques, especially not linked to the enhancement of stress tolerance. Only a very few articles have been published studying the role of PI signaling in plant environmental responses. One of them studied transgenic Arabidopsis lines overexpressing the ZmSEC14p gene (homologous to the PITP gene) from a cold-tolerant maize line. These transformant lines conferred tolerance to cold stress and they also upregulated the expression of $P L C$ genes, which are members of the calcium-signaling pathway (Wang et al. 2016). The role of the barley $H v S e c 14 p$ gene has recently been determined under water deficit conditions and salinity stress, using susceptible and tolerant barley genotypes (KiełbowiczMatuk et al. 2016). It was revealed that the $H v S e c 14 p$ expression level was strongly upregulated under drought stress and sodium treatment in the vegetative organs. In another study with Arabidopsis pi4k mutants, the double mutant lines displayed significantly delayed germination under low temperature compared to the wild-type, indicating higher cold sensitivity, thus suggesting the role of the $P I 4 K$ gene in cold tolerance (Delage et al. 2012). These results support the involvement of the PI signaling pathway in stress responses; however, there are many missing links in our understanding.
In our previous study, we have demonstrated that the $H v P I T P$ and $H v P I 4 K$ genes, members of the phospholipid signaling pathway, show circadian rhythm in barley. We also showed that their expression is modulated by the ratio of the illuminating red/far-red light (Gierczik et al. 2017). This experimental result, and also the fact that the PITP and the PI4K enzyme are responsible for the activation of $\mathrm{Ca}^{2+}$ channels and the release of secondary messenger molecules, suggested to us that these genes may play a role in the enhancement of certain abiotic stress tolerances, via the facilitation of the stress signal propagation. To test this hypothesis, the HvPITP and $H v P I 4 K$ genes were isolated from winter barley and overexpressed in a spring barley genotype. The effect of the transgenes on stress adaptation was analyzed by determining the response to salinity, frost, and hypoxic cold stress.

\section{Materials and Methods}

\section{Plasmid Construction, Plant Material, and Transgenic Plant Production}

The PITP and PI4K gene sequences were obtained from the NCBI nucleotide database as described previously (Gierczik et al. 2017). The AK374523 accession was selected as the target HvPITP gene, and the AK360859 accession was selected as the target $H v P I 4 K$ gene for transformation. The cDNAs were isolated from winter barley (Hordeum vulgare spp. vulgare) variety 'Nure'. Genes were reverse-transcribed (MMLV Reverse Transcriptase, Promega Corporation, Madison, WI, USA) from RNA isolated by TRIzol® Reagent (Invitrogen Corporation, Carlsbad, CA, USA); the samples were treated with DNase I enzyme (Promega Corporation, Madison, WI, USA). The cDNAs were amplified (AccuPrime $^{\mathrm{TM}}$ Pfx DNA Polymerase, Invitrogen Corporation, Carlsbad, CA, USA) using the primer pairs "PITP Gateway Fwd" (5'-CAC CAT GGT TCA GAT CAA GGA ATT CCG AAT C-3'), "PITP Gateway Rev" (5'-CTA CGT GCA GCT CCC CAT GAC TGC-3'), "PI4K Gateway Fwd" (5'-CAC CAT GTC ACA AGG GAT GAA CAT GTT CGT G-3'), and "PI4K Gateway Rev" (5'-CTA TTT CTC AAT ACC TTG CTG CAA GTA TTG-3'), including the 4 base pair sequence (CACC), which is necessary for directional cloning on the $5^{\prime}$ end of the forward primers. The amplicons were cloned into the pENTR/D-TOPO ${ }^{\circledR}$ (Invitrogen Corporation, Carlsbad, CA, USA) Gateway-based cloning vector. Then the LR recombination reaction between the cloning (donor) vectors and the pBract214 binary recipient vector (John Innes Centre, Norwich Research Park, Norwich, UK) was completed. In this construct, the maize ubiquitin promoter + intron $(U b i-1)$ sequences ensure the constitutive expression of the transgene. Immature embryos of the spring barley (Hordeum vulgare spp. vulgare) cv. 'Golden Promise' were 
transformed by Agrobacterium-mediated (A. tumefaciens strain AGL1) method (Bartlett et al. 2008; Harwood et al. 2009), using pBract214-HvPITP and pBract214-HvPI4K constructions (Fig. S1).

In our experimental system, different transgenic generations were used for the tests. Some tests were run on the segregating $T_{1}$ generation, but most of them were carried on homozygous $T_{2}$ or $T_{3}$ plants.

\section{Molecular Analysis of the Transgenic Lines}

In order to prove the presence of each essential element of the transgenes, genomic DNA samples were isolated from leaf tissue from all independent transformant lines (i.e., regenerated from different calli) by a DNeasy Plant Mini Kit (Qiagen ${ }^{\circledR}$, Hilden, Germany) according to the manufacturer's instructions. The DNA quantification was carried out by a NanoDrop 2000 Spectrophotometer (Thermo Fisher Scientific Inc., Wilmington, MA, USA). The presence of the transgene was confirmed by PCR, amplifying the $h p t$ selection marker gene (Stanley et al. 2011), the ubiquitin (promoter)/transgene, and transgene/NOS (terminator) regions of the constructions (as in Soltész et al. 2013). The "HvPITP Fwd" (5'-CAC CAT GGT TCA GAT CAA GGA ATT CCG AAT C-3'), "HvPITP Rev" (5'-CTA CGT GCA GCT CCC CAT GAC TGC-3'), "HvPI4K Fwd" (5'-TAC AGC TGG ACA GCG GTA TTC CTC TCC-3'), and "PI4K Rev" (5'-AAC TGG ATC CTT TTC TGG TGG TGC C-3') primer sequences were designed to amplify a 1214-bp (HvPITP Fwd + NOS), a 1013-bp (HvPITP Rev + ubiquitin), 1251-bp (HvPI4K Fwd + NOS), and a 1202-bp (HvPI4K Rev + ubiquitin) PCR product.

The determination of the transgene copy number in the $T_{0}$ and $\mathrm{T}_{1}$ generations was carried out at $\mathrm{g}$-Count ${ }^{\mathrm{TM}}$ service (IDna Genetics Ltd., Norwich, UK) using $h p t$ as the assay target. The zygosity of $T_{1}$ plants was deduced based on the copy number values of the $T_{0}$ and $T_{1}$ plants, and only homozygous $T_{1}$ plants were used to produce the genetically stable (i.e., non-segregating) $T_{2}$ seeds.

To determine the transgene expression levels, we used quantitative real-time PCR. Leaf samples of the $T_{1}$ plants were collected from five independent plants and homogenized into one sample for nucleic acid isolation. Total RNA was isolated by a RNeasy Plant Mini Kit (Qiagen $®$, Hilden, Germany) according to the provided protocol, and supplemented with DNA digestion with a DNase I Set (Zymo Research Corp., Irvine, CA, USA). RNA quantification was performed with a NanoDrop 2000 Spectrophotometer (Thermo Fisher Scientific Inc., Wilmington, MA, USA), while the RNA integrity and the DNA degradation were checked by agarose gel electrophoresis. cDNA syntheses were made with the M-MLV Reverse Transcriptase and oligo $(\mathrm{dT})_{15}$ primer (Promega Corporation, Madison, WI, USA) according to the instructions of the manufacturers. Gene expression levels were determined with a CFX96 Touch $^{\mathrm{TM}}$ Real-Time PCR Detection System (Bio-Rad Hungary Ltd., Budapest, Hungary) with the KAPA SYBR® FAST, Master Mix (2×), Universal qPCR Kit (Kapa Biosystems, Inc., Wilmington, MA, USA). Each cDNA sample was used for real-time qPCR in three amplifications and was considered as a technical replicate. The PITP, PI4K, and cyclophilin gene-specific primer sequences were taken from the literature (Burton et al. 2004; Gierczik et al. 2017). The melt curve analysis was performed in every case to confirm the amplification of a single gene product. The relative gene expression values were calculated by the $\Delta \Delta \mathrm{Ct}$ method (Livak and Schmittgen 2001) using cyclophilin as the reference gene. The untransformed, wild-type Golden Promise was used as a control for normalization.

\section{Plant Growth and Phenotypic Evaluation}

The homozygous $T_{2}$ generation was used for phenotyping. At developmental phase Z13 (Zadoks et al. 1974), i.e., the 3-leaf stage, the plants were placed into a vernalization chamber for 4 weeks $\left(0.9-5.9^{\circ} \mathrm{C}, 20-25 \mu \mathrm{mol} \mathrm{m}{ }^{-2} \mathrm{~s}^{-1}, 16 \mathrm{~h}\right.$ photoperiod). After vernalization, seven plants from each line were planted into plastic pots and placed into a plant growth chamber (Conviron PGR15; Controlled Environments Ltd.; Winnipeg, Manitoba, Canada). The growing medium was a 2:1:1 $(v / v / v)$ mixture of soil, sand, and humus; the temperature was $18 / 15^{\circ} \mathrm{C}$ (day/night) with $220 \mu \mathrm{mol} \mathrm{m} \mathrm{m}^{-2} \mathrm{~s}^{-1}$ light intensity and $75 \%$ RH. After 7 weeks, the temperature was raised to $22 / 20{ }^{\circ} \mathrm{C}$ (day/night), but the other environmental parameters were not changed.

Heading date and flowering date were recorded from each plant during the growing phase. After full ripening, all plants from each line were evaluated for phenotypic traits, which were plant height, dry weight of shoot biomass, length of head spike, grain number and weight of head spike, spike number per plant, and grain number and grain weight per plant as well as thousand grain weight (TGW).

\section{Photosynthetic Pigment Content}

The indirect measurement of the chlorophyll content of the leaves was recorded with a SPAD-502 Chlorophyll Meter (Minolta Co. Ltd., Osaka, Japan) after 9 weeks from planting, at the beginning of inflorescence development, i.e., earlyheading phase, Z51-52 (Zadoks et al. 1974). The measurements were made on the flag leaves of all seven plants from each line. The average of three SPAD values made from the midpoint of the leaves was calculated.

During the experiments, pale leaves or even albinism was detected in several cases. To quantify the photosynthetic pigment content of these abnormal leaves and every transgenic barley line (including the pale ones) and to compare them to 
the Golden Promise control genotype, seeds from the $T_{1}$ generation were germinated. In the case of the "pale leaves" phenotype, samples of similar ages were taken. Leaves from the wild-type Golden Promise variety and from green plants from each transgenic line were used as controls. Five independent leaves were measured in each case. The chlorophyll $a$, chlorophyll $b$, and total carotenoids were extracted with $80 \%$ acetone. The maximum absorptions of chlorophyll $a$, chlorophyll $b$, and total carotenoids $(664 \mathrm{~nm}, 646 \mathrm{~nm}$, and $470 \mathrm{~nm}$, respectively) were measured by a Cary 100 Scan UV-Visible spectrophotometer (Agilent Technologies, Santa Clara, CA, USA). The chlorophyll $a$, chlorophyll $b$, and total carotenoid contents were calculated according to the method of Lichtenthaler and Buschmann (2001). Photosynthetic pigment contents were calculated in $\mu \mathrm{g} \times \mathrm{g}^{-1}$ fresh weight.

\section{Frost Tests}

The wild-type Golden Promise and seeds from the $T_{1}$ and $T_{3}$ generations were used in two types of frost tests. One type was carried out with a cold hardening period, while a second one was run without it. For both experiments, the seeds were germinated as described above, then 20 individual seedlings were planted randomly into wooden boxes $(42 \times 30 \times 13 \mathrm{~cm})$ from each of the barley lines. The growing medium was as described above. The plantlets were grown in plant growth chambers with $16 \mathrm{~h}$ photoperiod, at $20 / 15^{\circ} \mathrm{C}$ (day/night) temperature, at $220 \mu \mathrm{mol} \mathrm{m} \mathrm{m}^{-2} \mathrm{~s}^{-1}$ light intensity under cool white fluorescent tubes (Sylvania 215 W F96 T12). To prevent inhomogeneity in plant development, the wooden boxes were randomized in the plant growth chamber every week. After 19 days of the growth period, at the 5-leaves stage (Z15, Zadoks et al. 1974), two different treatments were applied. For the first type of frost test, the $T_{1}$ plants were exposed to the cold hardening period before freezing. To ensure the cold hardening, the temperature was gradually decreased over 14 days to a continuous $+5 / 5{ }^{\circ} \mathrm{C}$ (other environmental parameters left unchanged). Then, to reach the freezing temperature, it was decreased gradually $\left(-0.6{ }^{\circ} \mathrm{C} / \mathrm{h}\right)$ to $-6 /-6{ }^{\circ} \mathrm{C}$. This $-6{ }^{\circ} \mathrm{C}$ freezing period was maintained for $24 \mathrm{~h}$. After the freezing process, the temperature was increased gradually $\left(+0.6{ }^{\circ} \mathrm{C} / \mathrm{h}\right.$ ) to $18{ }^{\circ} \mathrm{C}$ for recovery. In the second type of frost test, the $\mathrm{T}_{3}$ plants were subjected to the frost without any cold hardening period. For freezing, the temperature was decreased dramatically $\left(-3{ }^{\circ} \mathrm{C} / \mathrm{h}\right)$ to $-3{ }^{\circ} \mathrm{C}$ or to $-5{ }^{\circ} \mathrm{C}$. The lowest temperature $\left(-3{ }^{\circ} \mathrm{C}\right.$ or $\left.-5{ }^{\circ} \mathrm{C}\right)$ was applied for $16 \mathrm{~h}$ in both cases. In every frost test, when the temperature reached $0{ }^{\circ} \mathrm{C}$, the leaves were sprayed with distilled water to induce ice nucleation. After both types of frost tests, the leaves were completely cut off $2-3 \mathrm{~cm}$ above the crown. Then the plants were allowed stem elongation during the recovery period, which allowed the crown meristems to produce new tillers (Sutka 1981). The temperature in the recovery chamber was
$18 / 13{ }^{\circ} \mathrm{C}$ in every case, while the other environmental parameters were the same as in the growth period. After 3 weeks of recovery, the survival percentage (i.e., the ratio of the living and the total number of plants for each barley line) was calculated.

\section{$\mathrm{NaCl}$ Treatments}

Six PITP lines and four PI4K lines from the homozygous $T_{3}$ generation and the wild-type Golden Promise were used in this test. In three independent biological replicates, ten seeds were germinated on wet filter paper, moistened with halfstrength modified Hoagland solution (Table S1) or halfstrength modified Hoagland solution supplemented with $\mathrm{NaCl}$ to the final concentration $150 \mathrm{mM}$ (Hoagland and Arnon 1950). The seeds were kept in the dark at $26^{\circ} \mathrm{C}$ for 3 days. The length of the shoots and the length of the roots were measured at the end of the experiment.

In addition to the test above, seeds of six PITP lines and four PI4K lines from the homozygous $\mathrm{T}_{3}$ generation and the wild-type Golden Promise were germinated in Petri dishes wetted with distilled water. After 3 days at $26{ }^{\circ} \mathrm{C}, 10-10$ seedlings were tested in hydroponic-culture with halfstrength modified Hoagland solution (see above). Plastic pots were placed into the plant growth chamber under 16-h photoperiods, at $22 / 20^{\circ} \mathrm{C}$ (day/night) temperature with 120 $130 \mu \mathrm{mol} \mathrm{m} \mathrm{m}^{-2} \mathrm{~s}^{-1}$ light intensity. After 9 days, salt stress was induced by adding $150 \mathrm{mM} \mathrm{NaCl}$ to the nutrient solution. The control plants were grown without salt treatment. The nutrient solutions were renewed every 2 days, and the plastic pots were randomized in the plant growth chamber as well, to prevent inhomogeneity in plant development. The shoot length, shoot weight, root length, root weight, SPAD value (the method has already been described in phenotyping for traits section), and relative water content (RWC) were measured after 7 days. RWC was determined as RWC [\%] = (fresh weight - dry weight) / (turgid weight - dry weight $) \times 100$ (Schonfeld et al. 1988).

\section{Combined Hypoxia and Cold Stress}

The homozygous $T_{3}$ generation and the wild-type Golden Promise barley line as a control were used in this test. The environmental parameters were based on the Complex Stressing Vigor Test (Barla-Szabó and Dolinka 1988). One hundred seeds from each barley line were fully soaked in distilled water and were held at room temperature for 2 days. On the third day, without changing the water, the seeds were placed at $5{ }^{\circ} \mathrm{C} \pm 1{ }^{\circ} \mathrm{C}$ for another 2 days. After the combined hypoxia and cold stress, the seeds were aliquoted randomly to four replicates, rolled in paper towels, and placed vertically in glass beakers and held in $20{ }^{\circ} \mathrm{C} \pm 0.5{ }^{\circ} \mathrm{C}$. During the whole growing period, the paper rolls were randomized every 2 days 
to prevent inhomogeneity in development. After 8 days at $20{ }^{\circ} \mathrm{C}$, the survival percentage was calculated for each barley line. Following that, the vigor of the seeds was evaluated as well. Seedlings were considered highly vigorous if the length was larger than the $2 / 3$ average of the three longest ones from each replicate.

\section{Statistical Analysis}

For the statistical analyses, one-way ANOVA (analysis of variance) with least significant difference (LSD) or Tukey's-b post hoc test (if equal variances were assumed), Dunnett's T3 probe (if equal variances were not assumed), or MannWhitney $U$ nonparametric test was performed with the SPSS 16.0 software. The normality was tested by the KolmogorovSmirnov probe, while the homogeneity of the variances was tested by Levene's probe.

\section{Results and Discussion}

\section{Verification of Transgenic Barley Lines}

The coding regions of the HvPITP and $H v P I 4 K$ genes were cloned into the pBract 214 vector, especially designed for gene overexpression in cereal species. Immature Golden Promise spring barley embryos were transformed using pBract214HvPITP and pBract214-HvPI4K constructs, also carrying the $h p t$ selectable marker gene to produce hygromycinresistant transgenic plants. Only those plants which were originated from different calli lines were considered as independent transgenic lines. Altogether, 15 independent PITP and 13 independent $P I 4 K$ overexpressing lines were regenerated. The integration of the transgene was verified by PCR; all of the candidate transgenic lines proved to be PCR positive for the hpt gene and positive for the ubiquitin (promoter)/transgene and transgene/NOS (terminator) regions in the $\mathrm{T}_{0}$ generation, thus confirming that all the essential elements were successfully inserted, in the desired orientation, in all transgenic lines.

\section{Molecular Characterization of the Transgenic Lines}

The copy number estimation revealed in the $\mathrm{T}_{0}$ generation that the transformant barley lines contained the PITP gene in one, two, or six copies and the $P I 4 K$ gene in one or two copies (Table S2). Eleven out of 15 lines (73\%) contained the PITP gene as a single copy, while eight out of 13 lines (62\%) contained just one copy of the $P I 4 K$ gene. From all the independent transformant plants, only one (4\%), i.e., PITP L5, contained the transgene in more than two copies. These low copy numbers are indicating that our choice of Agrobacterium-mediated transformation protocol was correct. Our decision was based on the fact that $60 \%$ of the transgenic barley lines, which were produced by particle bombardment, contained more than eight transgene copies in their genome (Travella et al. 2005), and this very high number could be considered a disadvantage, because the multiple-transgene insertion often causes lower gene expression levels (reviewed by Dahleen and Manoharan 2007), and the production of homozygous lines is quite challenging. In a second study, from 260 independent barley transgenic lines produced by Agrobacterium-mediated transformation, almost half of the transformed lines contained the luciferase marker gene as a single copy, while only $8 \%$ of the transformant lines contained more than three copies of the marker gene (Bartlett et al. 2008). This tendency was also observed in transgenic rice produced by Agrobacterium-mediated methods; $30-40 \%$ of more than 200 analyzed plants contained the $h p t$ marker gene as a single copy (Sallaud et al. 2003).

To determine the uninduced PITP and PI4K gene expression levels of the transformant plants (Fig. 1), leaf samples were collected from control conditions (i.e., without any stress) from the segregating $T_{1}$ generation. We found that the PITP transgene expression values were much higher (20-60fold, Fig. 1a) than the $P I 4 K$ transgene values (3-7-fold, Fig. 1d) with the exception of the PI4K L6 line (23-fold, Fig. 1d) in the transformant lines compared to the non-transformant Golden Promise. To examine a possible interaction of the two genes, we determined the PITP expression levels in the PI4K lines and the PI4K expression levels in the PITP lines as well. The results showed that the transformed genes indeed have an influence on the expression levels of the other gene. The PITP transgene was expressed in PI4K lines two- to sixfold higher than in the wild-type (Fig. 1b), while the PI4K transgene was expressed in PITP lines two- to eightfold higher than in the control genotype (Fig. 1c). This evidence raises the possibility that the effects of the expression of the transformed gene influence (increase) the expression of the downstream element (i.e., PITP enhances PI4K), which, considering that the transporter PITP provides the substrate inositol for the kinase (PI4K), seems to be reasonable. However, it could also be concluded that the downstream element enhances the activity of the upper-stream element (i.e., PI4K enhances PITP) by an unknown feedback mechanism. These speculations, however, must undoubtedly be supported by other experimental data.

The relationship between the copy number of the transformant lines and the expression level of HvPITP or $H v P I 4 K$ genes was also analyzed; however, no correlation was observed between target gene expression level and copy number, neither for the PITP lines $\left(R^{2}=0.4935\right)$ nor for the PI4K lines $\left(R^{2}=0.0470\right)$. This finding is clearly demonstrated by comparing the PI4K L6 line, which showed the highest expression level among the PI4K lines; however, it contains only one transgene copy, with the PITP L9 line, which contained the PITP gene in two copies, but its expression level 
Fig. 1 Gene expression values of the HvPITP gene in PITP lines and PI4K lines (a and $\mathbf{b}$, respectively) and the $H v P I 4 K$ gene in PITP lines and PI4K lines (c and $\mathbf{d}$, respectively) from the segregating $T_{1}$ generation.

Transcript levels were calculated with the $\Delta \Delta \mathrm{Ct}$ method using cyclophilin as the reference gene and the Golden Promise (GP) wild-type line for the normalization. The values and the error bars that represent the standard deviation are originated from five independent plants and three technical replicates

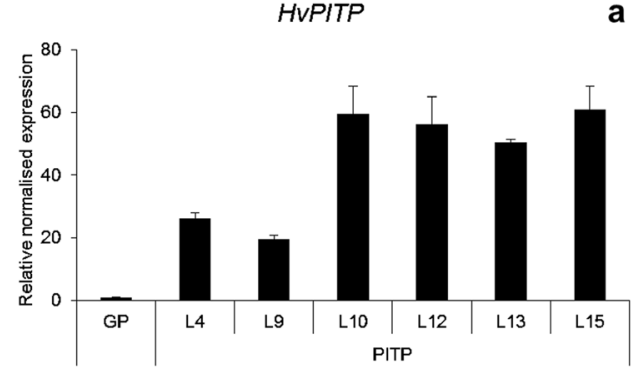

a

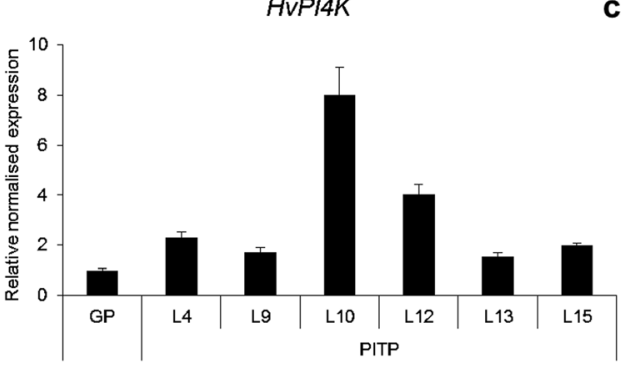

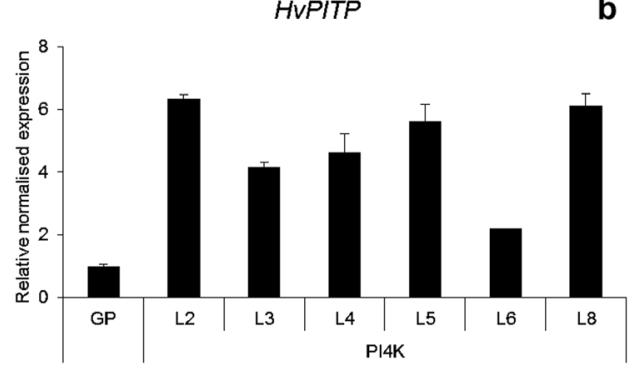

b

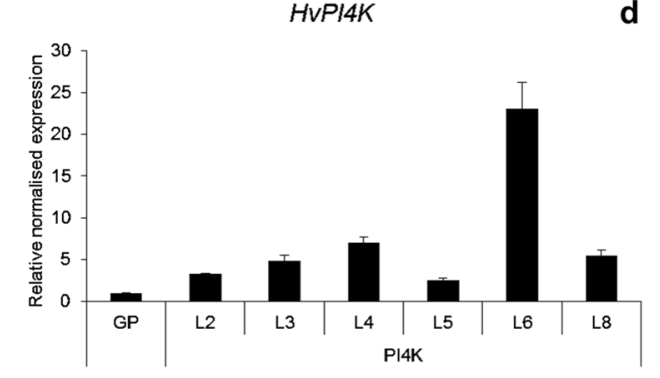

was the lowest of all the examined PITP lines. It has been shown in many studies that there is no clear evidence for strong correlation between transgene expression level and copy number in genetically modified plants. The differences in transgene expression level have often been explained by the chromosomal location of the transgene cassettes, the so-called position effect (Matzke and Matzke 1998).

\section{Developmental Disorders of the Transgenic Lines}

When $\mathrm{T}_{0}$ plants were regenerated and progressed in our system, it was observed that some plants, overexpressing either the HvPITP or the $H v P I 4 K$ genes, exhibited retarded flowering compared to the wild-type Golden Promise. We realized that the apex of these plants, although they moved from the vegetative phase into the generative phase, appeared stuck at Z45-50 (Zadoks et al. 1974) (Fig. S2a-b). In these plants, it seemed that the spikelet was not able to develop normally, so normal flowers or spikes with seeds were not developed. Beside these developmental disorders, lack of internodes, another abnormal phenotype, also appeared in the $\mathrm{T}_{0}$ generation (Fig. S2c).

In the segregating $T_{1}$ generation, some transgenic barley lines showed chlorophyll deficiency or even albinism (Fig. S2e). Such abnormalities have already been described in several publications for transformant plants (reviewed by Vyroubalová et al. 2011), but we found that the PITP and PI4K transformants showed this abnormality in a relatively higher rate. In the PI4K L6 line, $6.5 \%$ of the plants showed a pale leaf phenotype, while in the PI4K L4 line 6\%, and in the PITP L11 line 5\% of the plants showed albinism. Without exception, these plants grew slower than the wild-type Golden Promise or the rest of the transformant lines. This developmental disorder proved to be lethal from the third week after germination. In the case of the wild-type Golden Promise, no chlorophyll deficiency has ever been detected. Considering the fact that in our previous experiment, when transformant lines, carrying the transcription factor coding $C B F$ genes, were developed (Soltész et al. 2013) by exactly the same transformation system (vector, transformation method, recipient, etc.), hardly any albinism was recorded (unpublished data); we suppose that this result, found for the upstream regulators (PITP and PI4K), might be the side effect of the transgenes themselves (or it might be "position effect" as mentioned above).

In order to quantify the above mentioned observations, chlorophyll $a$, chlorophyll $b$ (Fig. 2a), and total carotenoid content (Fig. 2b) were determined in those $T_{1}$ lines which showed yellowish leaf phenotype or even albinism. There were no significant differences between the wild-type Golden Promise and those transgenic lines, which showed normal "green" leaf phenotype. "Green" (i.e., non-deficient) plants were also measured from those transgenic lines in which yellowish leaves or albinism had also appeared, but no significant differences were found between the green leaves and the wild-type Golden Promise. However, a dramatic decrease was detected in chlorophyll $a$, chlorophyll $b$, and total carotenoid content in the PI4K L6 line compared to the wild-type and the PI4K L6 "green" samples. It is well accepted that the ratio of chlorophyll $a / b$ is a good indicator of the greenness of leaves. The lower chlorophyll $a / b$ ratio (i.e., between 2.5 and 3.5) is typical of the healthy, dark-green leaves, while the higher chlorophyll $a / b$ ratio (i.e., between 4.0 and 10.0 ) is specific for etiolated leaves (Lichtenthaler and Buschmann 2001). The chlorophyll $a / b$ ratio in the wildtype Golden Promise and in the green leaves from the 
Chlorophyll $a+b$

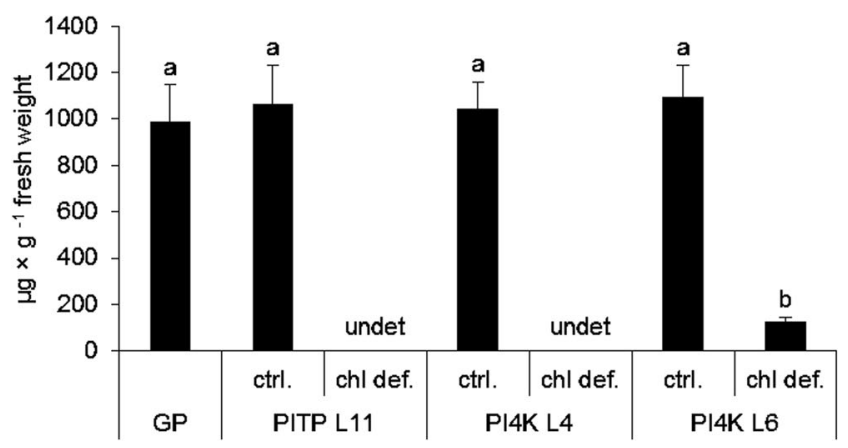

Fig. 2 Chlorophyll $a+b$ content (a) and total carotenoid content (b) of the PITP L11, PI4K L4, and PI4K L6 transgenic lines and the wild-type Golden Promise (GP). The values indicated by different letters are

transgenic lines was between 2.9 and 3.3, while in the yellowish leaf samples in the PI4K L6 line, the chlorophyll $a / b$ ratio was 3.8. Chlorophyll $a$, chlorophyll $b$, and total carotenoid content were undetectable in the case of the albino plants in the white plants of the PITP L11 and PI4K L4 lines, showing real albinism.

It is known that many factors might induce albinism during tissue culture methods. Among them are genetic factors, such as the position of the inserted gene in the host genome; several culture conditions; the type of medium used; and the species or the genotype of the recipient plant. A detailed study revealed that $45 \%$ of transformant callus lines yielded only albino plants. It was shown that the origin of the callus influenced the ratio of albinism, since $55 \%$ of the plants, which were regenerated from immature zygotic embryos, were normal green, while only $25 \%$ green plants were regenerated from microspore-derived embryos (Wan and Lemaux 1994). In another study, where particle bombardment was used to produce transformant wheat lines, some transformant lines had yellow-green appearance, compared to the dark-green host variety Bobwhite. This trait was noticeable before anthesis; furthermore, the leaves had a narrow and twisted shape (Bregitzer et al. 2006). In transgenic rice plants, yellowishgreenish leaves appeared in $T_{3}$ and $T_{4}$ generations as well, which were in contrast to the dark-green progenitor Xiushui 11 line. These transgenic plants grew slower and developed less tillers and their heights were circa $80 \%$ shorter, compared to the non-transformants (Shu et al. 2002).

In the $\mathrm{T}_{0}$ generation, some transgenic lines, both from PITP and PI4K, were unable to enter into the developmental phase Z30 (Zadoks et al. 1974) and remained at the tillering phase (Fig. S2d). Without exception, these plants were not able to produce seeds, so they were not sustainable lines. We observed another abnormality among the transgenics: in the homozygous $\mathrm{T}_{2}$ generation, some transgenic barley lines showed branchedspike morphology (Fig. S2f). This is not unique; it has been described as naturally occurring several times (reviewed by Terzi et al. 2017); however, the domesticated barley has a
Total carotenoids

b

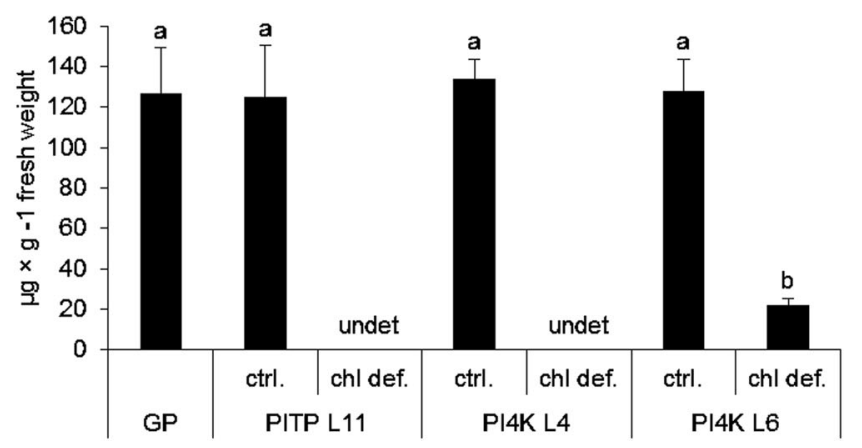

significantly different at $P<0.05$ level; "undet" means undetectable values. Error bars represent the standard deviation calculated from five independent biological replicates

branchless shaped spike. In this study, we demonstrated that the transgenes increased the number of branched spikes in both PITP and PI4K lines as well (Table S3). In the case of PITP L13 and PI4K L2, the branched-shaped morphology, as a developmental disorder of the spikes, was significantly increased due to the transgenes.

In several papers (Wang et al. 2008; Luo et al. 2012; Ku et al. 2013; Shen et al. 2015), the performance of the transgenics is compared not just to that of the progenitor wild-type line but to that of a transgenic control line also. These transgenic control lines contained only an empty vector, i.e., only the selection marker gene, but not the gene of interest, so these lines were suitable for studying the effect of the transformational procedure itself. It was recorded that these empty vector lines did not show either development differences or higher stress tolerance compared to the wild type. In our previous study (Soltész et al. 2013), where the pBract214 binary vector was used (just like in this study), the thorough experiments revealed that the transgenic control line, carrying an empty vector, showed no differences compared to the wild-type Golden Promise in either development or stress tolerance. Hence, in this study, only the wild-type Golden Promise was included as the control line in all experiments. We concluded that the revealed differences, in trait phenotype, developmental disorders, or stress tolerance, were therefore due to the HvPITP and HvPI4K transgenes and not because of the transformation event (see below).

Although plant transformation has a several-decade-long history, it is still not usually possible to control the location of transgene insertion into the host genome or the precise expression level of the transgene with conventional plant transformation methods. New genome editing techniques offer the possibility for targeted transgene insertion, but in the meantime, there are still unintended events and unpredictable consequences in phenotype. In the case of Arabidopsis, the floral dip method generates minimal variations; on the other hand, when tissue culture must be used, and this is the case for the cereals, the frequency of "non-intended" consequences is 
greater. In monocotyledonous plant species, such as wheat or barley, these unintended consequences can be divided into three main categories: (1) insertion effect, (2) positon effect, and (3) effect of regeneration technique (reviewed by Filipecki and Malepszy 2006). Another source of the (sometimes frequently) unwanted events is the transgene itself. The agronomic performances of transgenic wheat lines containing an additional high molecular weight glutenin subunit were assessed, and overall lower performances of the transgenic lines were detected. It was discussed that these deviations may have been caused by the selection marker gene or by somaclonal variation or by the altered transgene expression, i.e., because of the transgenes themselves (Bregitzer et al. 2006). However, no molecular evidence supported any of these assumptions. Such a kind of causality was presented for transgenic barley lines, when two $\mathrm{CBF}$ transcription factors $(C B F 14$ and $C B F 15)$ were introduced into the recipient Golden Promise line. These transgenes not only increased the level of frost tolerance but also led to delayed flowering and retardation in development. The molecular analysis of the transgenic lines proved that the increased expression of these regulatory genes enhanced the transcript levels of the catabolic gibberellic acid 2-oxidase enzyme gene, which led to the inactivation of bioactive gibberellic acids and the accumulation of DELLA protein (Soltész et al. 2013). So, in this case, the overproduction of a regulatory transgene induced an effector gene, involved in the hormonal system, whose alteration finally led to the unwanted phenotype, i.e., to growth retardation. In our current work, we have also shown that the transgenes, coding for very upstream signaling elements, thus influencing the expression of many downstream regulatory and effector genes, might be responsible for the unintended, unwanted phenotypes we have recorded.

\section{Phenotypic Analysis of the Homozygous $\mathrm{T}_{2}$ Generation}

A complex phenotypic evaluation was performed in the PITP and PI4K $T_{2}$ transgenic barley lines. Seven transgenic plants were measured from every line for every parameter, listed in Table 1. The PI4K L3 line was the only one from the 11 lines, which had an elevated SPAD value, compared to the wild-type Golden Promise. Therefore, we concluded that the overexpressed PITP and PI4K genes have no notable effect on the chlorophyll content. The plant heights of two out of 11 transgenic lines, namely PITP L13 and PI4K L6, were lower than those of the wild-type; moreover, the length of the head spike was also reduced only in these two transgenic barley lines, compared to that of the Golden Promise. The heading and the flowering dates were not changed dramatically by the influence of the PITP and PI4K transgenes; only PI4K L5 in the heading and PITP L13 in the flowering date showed a significant difference compared to the wild-type Golden
Promise. The total dry weights of shoot biomass were significantly higher in the PITP L10 line than in Golden Promise, while PITP L15 and PI4K L2 showed a significant decrease. Three out of 11 lines, namely PITP L13, PI4K L5, and PI4K L6, showed a significant increase in spike number per plant, compared to the wild-type. The grain weight of the head spike was decreased significantly in the PITP L13, PI4K L2, PI4K L5, and PI4K L6 lines compared to the Golden Promise; moreover, from these four lines, the PI4K L5 and PI4K L6 showed a significant decrease in the grain number of the spike as well. In the PITP L13, PITP L15, PI4K L5, and PI4K L6 lines, a significant decrease in grain number per plant was recorded. Furthermore, in the PITP L13, PITP L15, and PI4K L5 lines, a significant decrease was revealed in the grain weight per plant as well. Above all, the TGW values were reduced significantly compared to the Golden Promise in the PITP L13, PI4K L2, and PI4K L6 lines. Taken together, several transgenic barley lines showed significant reduction in the agronomically relevant phenotypic traits, but there were also some which did not differ significantly from the wild-type (e.g., PITP L4 or PITP L12).

Similar results were obtained with the TGW reduction among transgenic barley lines. In a complex study, where agronomic characteristics of the Golden Promise-based transgenic barley lines were compared, it was revealed (Horvath et al. 2001) that the average TGWs of transgenic lines showed 30 $40 \%$ weight reduction in 2 years in field conditions. In this experiment, the transgenic barley lines were tested in an irrigated area as well, and it was found that the yield of the transgenic lines decreased to circa $6.0 \mathrm{tha}^{-1}$, while a $7.7-\mathrm{t} \mathrm{ha}^{-1}$ yield was harvested for the progenitor Golden Promise line.

In our experiment, a detailed comparison of the PITP L12 and PITP L13 lines revealed some interesting differences as well. The PITP L13 line showed dwarfism and showed delay in flowering, but this line developed significantly more spikes per plant. Furthermore, this PITP L13 line showed a much more branched spike morphology $16.1 \%(P=0.006)$ too. However, it should be also noted that these spikes were much shorter and contained fewer seeds and, also, the grain weight of the head spike was just half of those in the PITP L12 lines. The PITP L13 line had fewer grains per plant and lighter grain weight per plant, and the TGW was also lighter compared to that of the PITP L12 line. Since both lines contained the transgene only in one copy, and there was no difference between the transgene expression levels due to copy number, the molecular explanation for these differences is still unclear. One explanation might be the site of the insertion of the transgenes in the host genome, but the clarification of this assumption requires further work.

\section{Frost Tolerance Testing}

To test whether these transgenes have any effect on plant frost tolerance, the transformant barley lines and the wild-type 
Table 1 Phenotypic evaluation of the PITP and PI4K transgenic barley lines. The numbers in the table represent the average value and the standard deviation of seven plants from the homozygous $T_{2}$ generation in each line. Values indicated by asterisks represent significant increase (green cells) and significant decrease (red cells) from the wild-type Golden Promise (GP) at $P \leq 0.001(* * *), 0.001<P \leq 0.01(* *)$, and $0.01<P \leq 0.05(*)$ levels

\begin{tabular}{|c|c|c|c|c|c|c|c|c|c|c|c|}
\hline \multirow{2}{*}{ Lines } & \multirow{2}{*}{ GP } & \multicolumn{6}{|c|}{ PITP } & \multicolumn{4}{|c|}{$\mathrm{PI} 4 \mathrm{~K}$} \\
\hline & & L4 & L9 & L10 & L12 & L13 & L15 & L2 & L3 & L5 & L6 \\
\hline $\begin{array}{l}\text { Chlorophyll } \\
\text { content } \\
\text { (SPAD } \\
\text { value) }\end{array}$ & $\begin{array}{l}46.6 \\
\pm 4.9\end{array}$ & $\begin{array}{l}49.7 \\
\pm 4.9\end{array}$ & $\begin{array}{l}47.9 \\
\pm 4.3\end{array}$ & $\begin{array}{l}50.5 \\
\pm 3.7\end{array}$ & $\begin{array}{l}46.8 \\
\pm 3.4\end{array}$ & $\begin{array}{l}44.0 \\
\pm 4.7\end{array}$ & $\begin{array}{l}50.2 \\
\pm 5.4\end{array}$ & $\begin{array}{l}44.0 \\
\pm 5.9\end{array}$ & $\begin{array}{c}52.1^{*} \\
\pm 6.5\end{array}$ & $\begin{array}{l}45.9 \\
\pm 4.7\end{array}$ & $\begin{array}{l}45.1 \\
\pm 5.7\end{array}$ \\
\hline $\begin{array}{c}\text { Plant } \\
\text { height } \\
{[\mathrm{cm}]}\end{array}$ & $\begin{array}{l}45.4 \\
\pm 2.5\end{array}$ & $\begin{array}{l}44.4 \\
\pm 1.7\end{array}$ & $\begin{array}{l}46.0 \\
\pm 2.5\end{array}$ & $\begin{array}{l}46.0 \\
\pm 1.5\end{array}$ & $\begin{array}{l}46.1 \\
\pm 2.4\end{array}$ & $\begin{array}{l}42.0^{*} \\
\pm 2.6\end{array}$ & $\begin{array}{l}48.1 \\
\pm 2.7\end{array}$ & $\begin{array}{l}43.6 \\
\pm 3.5\end{array}$ & $\begin{array}{l}45.1 \\
\pm 2.5\end{array}$ & $\begin{array}{l}45.0 \\
\pm 2.9\end{array}$ & $\begin{array}{c}42.0^{*} \\
\pm 2.0\end{array}$ \\
\hline $\begin{array}{l}\text { Heading } \\
\text { date (days } \\
\text { from } \\
\text { planting) }\end{array}$ & $\begin{array}{l}56.7 \\
\pm 1.8\end{array}$ & $\begin{array}{l}56.1 \\
\pm 1.5\end{array}$ & $\begin{array}{l}56.7 \\
\pm 2.1\end{array}$ & $\begin{array}{l}56.0 \\
\pm 1.8\end{array}$ & $\begin{array}{l}55.3 \\
\pm 2.1\end{array}$ & $\begin{array}{l}57.7 \\
\pm 1.0\end{array}$ & $\begin{array}{l}55.3 \\
\pm 1.4\end{array}$ & $\begin{array}{l}55.4 \\
\pm 1.6\end{array}$ & $\begin{array}{l}55.3 \\
\pm 1.0\end{array}$ & $\begin{array}{c}54.7^{*} \\
\pm 1.4\end{array}$ & $\begin{array}{l}57.6 \\
\pm 1.3\end{array}$ \\
\hline $\begin{array}{l}\text { Flowering } \\
\text { date (days } \\
\text { from } \\
\text { planting) }\end{array}$ & $\begin{array}{l}59.1 \\
\pm 1.6\end{array}$ & $\begin{array}{l}58.3 \\
\pm 1.0\end{array}$ & $\begin{array}{l}58.9 \\
\pm 2.0\end{array}$ & $\begin{array}{l}58.7 \\
\pm 1.8\end{array}$ & $\begin{array}{l}58.4 \\
\pm 2.3\end{array}$ & $\begin{array}{l}61.3^{*} \\
\pm 1.5\end{array}$ & $\begin{array}{l}58.7 \\
\pm 1.4\end{array}$ & $\begin{array}{l}58.1 \\
\pm 1.3\end{array}$ & $\begin{array}{l}57.9 \\
\pm 1.1\end{array}$ & $\begin{array}{l}58.6 \\
\pm 1.0\end{array}$ & $\begin{array}{l}59.9 \\
\pm 1.5\end{array}$ \\
\hline $\begin{array}{l}\text { Dry } \\
\text { weight of } \\
\text { shoot } \\
\text { biomass } \\
\text { [g] }\end{array}$ & $\begin{array}{l}14.5 \\
\pm 1.9\end{array}$ & $\begin{array}{l}14.3 \\
\pm 2.5\end{array}$ & $\begin{array}{l}13.4 \\
\pm 2.5\end{array}$ & $\begin{array}{l}17.3^{*} \\
\pm 2.5\end{array}$ & $\begin{array}{l}13.4 \\
\pm 2.0\end{array}$ & $\begin{array}{l}14.3 \\
\pm 2.6\end{array}$ & $\begin{array}{l}11.5^{*} \\
\pm 0.7\end{array}$ & $\begin{array}{l}11.6^{*} \\
\pm 2.5\end{array}$ & $\begin{array}{l}12.4 \\
\pm 1.4\end{array}$ & $\begin{array}{l}13.1 \\
\pm 2.1\end{array}$ & $\begin{array}{l}13.1 \\
\pm 1.5\end{array}$ \\
\hline $\begin{array}{l}\text { Spike } \\
\text { number } \\
\text { per plant } \\
\text { (pc) }\end{array}$ & $\begin{array}{l}10.0 \\
\pm 2.8\end{array}$ & $\begin{array}{c}8.3 \\
\pm 1.5\end{array}$ & $\begin{array}{c}9.1 \\
\pm 2.5\end{array}$ & $\begin{array}{r}12.3 \\
\pm 1.7\end{array}$ & $\begin{array}{l}10.1 \\
\pm 2.5\end{array}$ & $\begin{array}{l}13.3^{*} \\
\pm 4.1\end{array}$ & $\begin{array}{c}7.6 \\
\pm 1.1\end{array}$ & $\begin{array}{l}10.0 \\
\pm 2.0\end{array}$ & $\begin{array}{c}9.6 \\
\pm 2.1\end{array}$ & $\begin{array}{l}14.4^{* *} \\
\pm 3.7\end{array}$ & $\begin{array}{l}14.9^{* * *} \\
\pm 2.5\end{array}$ \\
\hline $\begin{array}{l}\text { Length of } \\
\text { head } \\
\text { spike }[\mathrm{cm}]\end{array}$ & $\begin{array}{c}9.3 \\
\pm 0.8\end{array}$ & $\begin{array}{c}9.1 \\
\pm 0.5\end{array}$ & $\begin{array}{c}9.0 \\
\pm 0.4\end{array}$ & $\begin{array}{c}9.6 \\
\pm 0.9\end{array}$ & $\begin{array}{c}9.1 \\
\pm 1.2\end{array}$ & $\begin{array}{l}8.2^{*} \\
\pm 1.0\end{array}$ & $\begin{array}{c}9.4 \\
\pm 0.6\end{array}$ & $\begin{array}{c}8.8 \\
\pm 0.8\end{array}$ & $\begin{array}{c}8.4 \\
\pm 0.9\end{array}$ & $\begin{array}{c}8.4 \\
\pm 0.7\end{array}$ & $\begin{array}{c}7.4^{* * *} \\
\pm 1.2\end{array}$ \\
\hline $\begin{array}{l}\text { Grain } \\
\text { weight of } \\
\text { head } \\
\text { spike }[g]\end{array}$ & $\begin{array}{l}0.99 \\
\pm 0.2\end{array}$ & $\begin{array}{l}0.91 \\
\pm 0.2\end{array}$ & $\begin{array}{l}0.89 \\
\pm 0.1\end{array}$ & $\begin{array}{l}0.89 \\
\pm 0.3\end{array}$ & $\begin{array}{l}0.85 \\
\pm 0.2\end{array}$ & $\begin{array}{c}0.46^{\star * *} \\
\pm 0.3\end{array}$ & $\begin{array}{l}0.77 \\
\pm 0.1\end{array}$ & $\begin{array}{c}0.70^{*} \\
\pm 0.3\end{array}$ & $\begin{array}{l}0.90 \\
\pm 0.2\end{array}$ & $\begin{array}{l}0.64^{\star *} \\
\pm 0.1\end{array}$ & $\begin{array}{c}0.44^{* * *} \\
\pm 0.2\end{array}$ \\
\hline $\begin{array}{c}\text { Grain } \\
\text { number of } \\
\text { head } \\
\text { spike }(p c)\end{array}$ & $\begin{array}{l}28.4 \\
\pm 2.0\end{array}$ & $\begin{array}{l}25.6 \\
\pm 4.6\end{array}$ & $\begin{array}{l}24.6 \\
\pm 2.9\end{array}$ & $\begin{array}{l}25.6 \\
\pm 6.6\end{array}$ & $\begin{array}{l}24.0 \\
\pm 4.7\end{array}$ & $\begin{array}{c}18.0 \\
\pm 11.0\end{array}$ & $\begin{array}{l}24.1 \\
\pm 2.0\end{array}$ & $\begin{array}{l}22.4 \\
\pm 6.6\end{array}$ & $\begin{array}{l}26.9 \\
\pm 2.7\end{array}$ & $\begin{array}{l}18.3^{* *} \\
\pm 3.4\end{array}$ & $\begin{array}{l}16.9^{*} \\
\pm 5.2\end{array}$ \\
\hline $\begin{array}{l}\text { Grain } \\
\text { number } \\
\text { per plant } \\
(\mathrm{pc})\end{array}$ & $\begin{array}{l}164.0 \\
\pm 17.4\end{array}$ & $\begin{array}{r}131.7 \\
\pm 46.6\end{array}$ & $\begin{array}{l}130.6 \\
\pm 15.2\end{array}$ & $\begin{array}{l}160.3 \\
\pm 42.3\end{array}$ & $\begin{array}{r}128.0 \\
\pm 29.6\end{array}$ & $\begin{array}{l}114.4^{* *} \\
\pm 42.4\end{array}$ & $\begin{array}{l}113.6^{* *} \\
\pm 16.7\end{array}$ & $\begin{array}{r}141.3 \\
\pm 50.4\end{array}$ & $\begin{array}{r}147.3 \\
\pm 21.7\end{array}$ & $\begin{array}{l}122.3^{*} \\
\pm 17.6\end{array}$ & $\begin{array}{l}107.1^{* *} \\
\pm 53.1\end{array}$ \\
\hline $\begin{array}{c}\text { Grain } \\
\text { weight per } \\
\text { plant [g] }\end{array}$ & $\begin{array}{r}4.96 \\
\pm 0.52\end{array}$ & $\begin{array}{c}4.37 \\
\pm 1.58\end{array}$ & $\begin{array}{l}4.40 \\
\pm 0.49\end{array}$ & $\begin{array}{l}4.79 \\
\pm 1.46\end{array}$ & $\begin{array}{c}3.95 \\
\pm 1.06\end{array}$ & $\begin{array}{l}2.45^{* *} \\
\pm 0.95\end{array}$ & $\begin{array}{l}3.34^{* *} \\
\pm 0.40\end{array}$ & $\begin{array}{l}3.66 \\
\pm 1.30\end{array}$ & $\begin{array}{c}4.31 \\
\pm 0.80\end{array}$ & $\begin{array}{l}3.74^{*} \\
\pm 0.49\end{array}$ & $\begin{array}{c}2.59 \\
\pm 1.27\end{array}$ \\
\hline $\begin{array}{l}\text { Thousand } \\
\text { grain } \\
\text { weight [g] }\end{array}$ & $\begin{array}{l}30.4 \\
\pm 3.4\end{array}$ & $\begin{array}{l}33.2 \\
\pm 3.6\end{array}$ & $\begin{array}{l}33.8 \\
\pm 2.3\end{array}$ & $\begin{array}{l}29.5 \\
\pm 3.9\end{array}$ & $\begin{array}{l}30.8 \\
\pm 3.6\end{array}$ & $\begin{array}{l}21.2^{\star \star \star} \\
\pm 3.0\end{array}$ & $\begin{array}{l}29.7 \\
\pm 3.8\end{array}$ & $\begin{array}{c}26.4^{*} \\
\pm 4.1\end{array}$ & $\begin{array}{l}29.3 \\
\pm 3.1\end{array}$ & $\begin{array}{l}30.7 \\
\pm 2.6\end{array}$ & $\begin{array}{c}24.4^{* *} \\
\pm 2.9\end{array}$ \\
\hline
\end{tabular}

Golden Promise were tested in two kinds of frost tests, described by Sutka (1981). Since the two type of frost tests were not performed at the same time, the number of the tested lines was different in the two experiments. In the first frost test, after a growth period, 20-20 plants of the segregating $T_{1}$ generation (including null segregants) from each line were cold hardened for 4 weeks and then frozen at $-6^{\circ} \mathrm{C}$. After 3 weeks of recovery, the plants were scored and the survival percentage was calculated. The PITP L9 and PITP L13 lines proved to be the most frost resistant compared to the wild-type Golden Promise; twice as many plants survived this frost test at $-6{ }^{\circ} \mathrm{C}$ than the control line (Fig. 3a). The PITP L9 line was the most frost resistant among the transformant lines; $45 \%(P=0.041)$ of the plants survived the $-6^{\circ} \mathrm{C}$ frost period. Among the PI4K lines, two lines (PI4K L4 and PI4K L8) showed a small but not significant increase in frost tolerance. In the second type of frost test, the 
$\mathrm{T}_{3}$ homozygous plants were subjected to the frost without any cold hardening period. These non-cold-acclimated plants were frozen at $-3{ }^{\circ} \mathrm{C}$ and $-5^{\circ} \mathrm{C}$. No significant difference was found between the transformant lines and the wild-type Golden Promise when the freezing temperature was $-3{ }^{\circ} \mathrm{C}$ (Fig. 3b). On the other hand, the $-5^{\circ} \mathrm{C}$ freezing temperature seemed to be lethal to all the tested transformant lines and the wild-type Golden Promise; none of the non-acclimated plants survived this low temperature.

These results indicate that the overexpression of two upstream elements of the phosphoinositol signaling pathway can result in a slightly elevated level of cold stress tolerance. To our best knowledge, very few papers focus on the involvement of PI signaling components in plant abiotic stresses, such as low temperature tolerance. On the other hand, it also became clear that the overexpression of these phospholipid signaling elements may not be sufficient for increased freezing tolerance. We found that cold — as a signal — is really required to improve cold tolerance in the transformant barley lines. Why is cold as a signal essential? We do not have any experimental explanation at the moment-just a speculation. We suppose that the overexpression of the PITP and PI4K genes leads to an excess, therefore an easier access to these molecules in the cells. This abundance makes the de novo synthesis of these elements unnecessary, which ensures this early response to be more effective. And this more efficient response leads to an increased level of cold stress tolerance in the end.

The C-repeat binding factor $(\mathrm{CBF})$ transcription factors are one of the most important and well-described cold stress-related genes in plants. They show high expression levels in low temperature and they regulate many cold-responsive genes, the socalled CBF-regulon (this topic is reviewed by Thomashow (1999). In the PITP and PI4K transformant lines, the transgenes are regulated by the ubiquitin constitutive promoter, which ensures strong transgene expression levels (Fig. 1). Since we found several improvements in the frost tolerance of some transgenic lines, we determined the gene expression levels of the most important $H v C B F$ s that are known to play a pivotal role in cold stress responses (e.g., $H v C B F 4 B, H v C B F 9, H v C B F 12$, and $H v C B F 14$ ). The real-time PCR method used was the same as in the molecular analysis of the transgenic lines section. The primer sequences were taken from the literature (Morran et al. 2011; Dhillon et al. 2017; Gierczik et al. 2017). Despite the constitutive promoter, we could not detect any difference between the transgenic lines and the wild-type Golden Promise (Fig. S3a-d) for any of the studied genes.

The sudden burst of intracellular $\mathrm{Ca}^{2+}$ after a short exposure of cold stress is long known. The fact that the CBF transcription factors are key players in cold stress regulation has been confirmed by dozens of papers in dozens of plant species, but very few papers focus on the role of the upstream or intermediate elements. The direct connection between calcium signaling and the induction of $C B F$ genes was suggested by showing that the calmodulin-binding transcriptional activator (CAMTA) was able to bind to the $C B F 2$ gene promoter in Arabidopsis (Doherty et al. 2009). Here, we show that the two very upstream $\mathrm{Ca}^{2+}$ signaling elements may play roles in the increased level of frost tolerance; however, since no induced $C B F$ expression levels were recorded, this response is not due to the activation of the CBF-regulon.

\section{Salt Stress Responses}

Among the few papers published on the effect of PI pathway elements on abiotic stress tolerance, Kiełbowicz-Matuk et al. (2016) recently tested salt stress-susceptible and tolerant barley genotypes. It was revealed that the barley PITP homologue gene, HvSEC14p, was upregulated not only at the transcriptional but also at the protein level. This result suggested that we should test our PITP and PI4K transgenic barley lines under $\mathrm{NaCl}$ stress. Ten transgenic lines from the homozygous $\mathrm{T}_{3}$ generation with the wild-type Golden Promise were tested at two developmental phases. Besides the control (i.e., no salt), $150 \mathrm{mM} \mathrm{NaCl}$ treatment was applied during germination. We found differences (but not significant) between the control and the salt stress treatment in the shoot or in the root length;

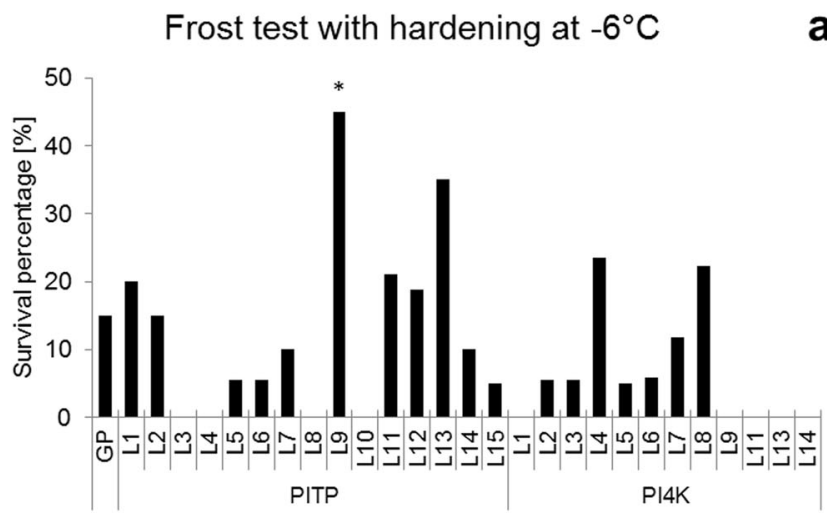

a



Fig. 3 Survival percentage of transgenic barley lines and the wild-type Golden Promise (GP) in the frost test at $-6{ }^{\circ} \mathrm{C}(\mathbf{a})$ and $-3{ }^{\circ} \mathrm{C}(\mathbf{b})$. Values indicated by asterisk are significantly different from the wild-type Golden Promise at the $0.01<P \leq 0.05(*)$ level 
however none of the transgenic lines showed any better performance than the Golden Promise line (Fig. S4a-b, respectively). In a second study, the salinity tolerance of the PITP and PI4K barley lines was tested in hydroponic conditions. Again, no significant differences were detected between the transformant lines and the progenitor Golden Promise in the shoot length, shoot weight, root length, root weight, SPAD value, or the RWC after 1 week stress (Fig. S5a-f, respectively).

Summarizing our results, we could not confirm the involvement of the PITP (or PI4K) signaling elements in salt stress. One of the obvious explanations is that two different experimental systems were used (different barley lines, salt concentration, developmental stage of the plants tested). Clearly, more experiments should be performed to clarify this question.

\section{Combined Hypoxia with Low-Temperature Stress}

With Golden Promise as a control line, five PITP and three PI4K transformant barley lines were used during a combined hypoxia and simultaneous cold stress. The applied stresses proved to be almost lethal to the wild-type barley line, while some of the transformant lines suffered less damage (Fig. 4). The survival percentages of the PITP L4, PITP L15, PI4K L2, and PI4K L5 lines were nearly the same, but a slight increase was observed compared to the Golden Promise. In the case of PI4K L3, a notable increase $(P=0.005)$ was detected in survival percentage compared to the wild-type line; $10 \%$ of the seeds could germinate after the combined hypoxia and cold stress. Furthermore, the PI4K L3 line showed not only a significantly increased germination percentage but also a significantly increased $(P=0.031)$ high vigor percentage (Table S4).

Cereals are obligate aerobes; therefore, oxygen deficiency (hypoxia) or its total absence (anoxia) is a significant stress for them. Due to frequently occurring floods in autumn or spring, young seedlings often suffer hypoxic conditions in the field. As a consequence, the loss in yield could vary from 10 to more than $50 \%$. Among the cereals, barley is very sensitive to hypoxia (Dennis et al. 2000). The importance of the increase in cytosolic calcium level in eukaryotic cells under oxygen deficiency is well known. Elevated cytosolic $\mathrm{Ca}^{2+}$ levels were detected within the first minute of exposure to anoxia conditions in maize cells where $\mathrm{Ca}^{2+}$ influx originated mainly from the mitochondria (Subbaiah et al. 1998) as it could be inhibited with ruthenium red, a known inhibitor of intracellular membrane $\mathrm{Ca}^{2+} / \mathrm{H}^{+}$-antiporter (Subbaiah et al. 1994). These data support our assumptions that the elevated hypoxic stress tolerance of our transgenic lines, which are overexpressing regulators known to be involved in $\mathrm{Ca}^{2+}$ signaling, is really due to the elevated level of intercellular $\mathrm{Ca}^{2+}$. However, this hypothesis requires some more direct experimental proof.

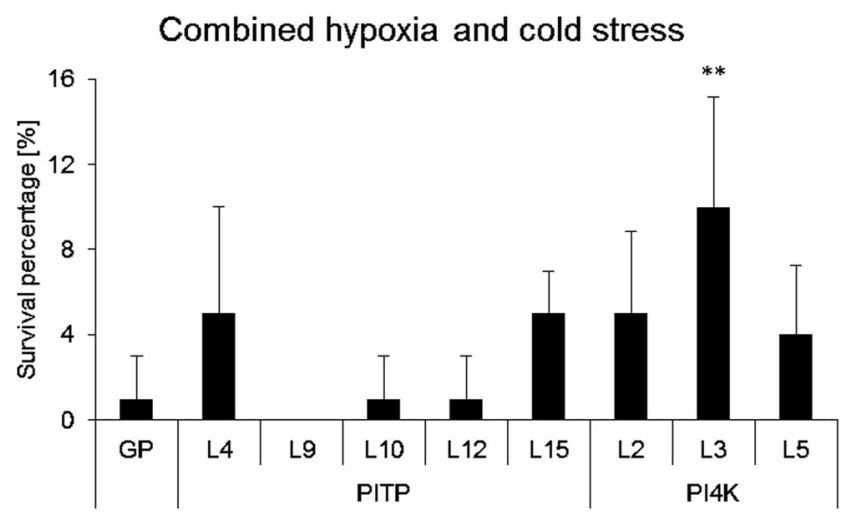

Fig. 4 Survival percentage of five PITP and three PI4K transformant barley lines and the wild-type Golden Promise (GP) in combined hypoxia and cold stress. Mean and standard deviation values were calculated from four replicates, which were originated from 25 to 25 seeds in every barley line. Values indicated by asterisks are significantly different from the wild-type Golden Promise at the $P \leq 0.001$ (***), $0.001<P \leq 0.01$ (**), and $0.01<P \leq 0.05(*)$ levels

\section{Conclusions}

A huge number of articles have already shown that the overexpression of transcription factors or effector genes could cause a notable increase in different abiotic stress tolerances (reviewed by Mickelbart et al. 2015 and Lata et al. 2011). Many of these studies aimed to prove the involvement of the gene of interest in the given stress or response by overexpression, or much less frequently by silencing. Such studies further illustrate the value of plant transformation as an important method in gene function analyses over decades. In this study, we examined the effect of the overexpression of HvPITP and HvPI4K genes in the model cereal plant, barley. The two studied genes code for the very first elements of the phosphoinositol signaling pathway. We aimed to test whether these early regulators had any role in abiotic stress tolerance. Our study also investigated whether an excess of an upstream signaling element would be sufficient to induce downstream cellular processes which finally lead to the increase of such a complex phenomenon as abiotic stress tolerance, or whether several other factors (i.e., other signaling pathways) are also required. To answer these questions, we have developed overexpressing transgenic barley lines. However, since many transgenic lines showed developmental disorders in this study, we concluded that the overexpression of genes from the very beginning of the signal transduction pathway resulted in more phenotypic "anomalies" than the overexpression of more specific effector genes or even their transcription factors. So, from economic and agricultural points of view, it seems that the overexpression of an upstream element is not the best choice to improve abiotic stress tolerance in transgenic plant production. On the other hand, since we could show that the HvPITP and HvPI4K genes do indeed play a role in cold tolerance and hypoxia tolerance, we concluded that overexpression of an early signaling element is a useful method for gene function analysis. 
Acknowledgments This work was supported by the Hungarian Scientific Research Fund "PD-OTKA" 116564 and by the EFOP-3.6.3-VEKOP16-2017-00008 projects. The project was co-financed by the European Union and the European Social Fund. Alexandra Soltész is granted by János Bolyai Research Grant (BO/00382/13). The authors wish to thank Mónika E. Fehér, Imréné Horváth, and Zsófia Ihász for their excellent technical assistance.

Author Contributions KG performed the real-time PCR experiments and the abiotic stress tests, carried out the data analyses, and wrote the manuscript. ASz and KG genotyped the barley lines. MA measured the photosynthetic pigment content. ZsMT, IV, and AS performed the plant transformation. AS carried out the in vitro works. BT initiated and managed partially this study. AV managed and supervised this study. WH, GG, AS, and $\mathrm{AV}$ revised the manuscript.

Funding Information Open access funding provided by MTA Centre for Agricultural Research (MTA ATK).

\section{Compliance with Ethical Standards}

Conflict of Interest The authors declare that they have no conflict of interest.

Abbreviations ANOVA, analysis of variance; $\mathrm{CBF}$, C-repeat binding factor; Chl, chlorophyll; $\mathrm{Ct}$, threshold cycle; cv, convarietas; DAG, diacylglycerol; DNA, deoxyribonucleic acid; Fwd, forward (primer); GP, Hordeum vulgare L. cv. 'Golden Promise'; hpt, hygromycin phosphotransferase (marker gene); $\mathrm{IP}_{3}$, inositol 1, 4, 5-triphosphate; $P$, probability level; PCR, polymerase chain reaction; PI, phosphatidylinositol; PI4K, phosphatidylinositol 4-kinase; PI4P, phosphatidylinositol 4-phosphate; PIP $_{2}$, phosphatidylinositol 4, 5-bisphosphate; PITP, phosphatidylinositol transfer protein; PLC, phospholipase C; Rev, reverse (primer); RWC, relative water content; SPAD, soil-plant analysis development; $\mathrm{T}_{x}, x^{\text {th }}$ transgenic generation; TGW, thousand grain weight

\section{Two-Letter Prefix in Front of Gene Names Hv, Hordeum vulgare L.; Zm,} Zea mays L.

Open Access This article is distributed under the terms of the Creative Commons Attribution 4.0 International License (http:// creativecommons.org/licenses/by/4.0/), which permits unrestricted use, distribution, and reproduction in any medium, provided you give appropriate credit to the original author(s) and the source, provide a link to the Creative Commons license, and indicate if changes were made.

\section{References}

Barla-Szabó G, Dolinka B (1988) Complex stressing vigour test: a new method for wheat and maize seeds. Seed Sci Technol 16:63-73

Bartlett JG, Alves SC, Smedley M, Snape JW, Harwood WA (2008) High-throughput Agrobacterium-mediated barley transformation. Plant Methods 4:22. https://doi.org/10.1186/1746-4811-4-22

Bregitzer P, Blechl AE, Fiedler D, Lin J, Sebesta P, de Soto JF, Chicaiza O, Dubcovsky J (2006) Changes in high molecular weight glutenin subunit composition can be genetically engineered without affecting wheat agronomic performance. Crop Sci 46:1553-1563. https://doi. org/10.2135/cropsci2005.10-0361

Burton RA, Shirley NJ, King BJ, Harvey AJ, Fincher GB (2004) The CesA gene family of barley. Quantitative analysis of transcripts reveals two groups of co-expressed genes. Plant Physiol 134:224-236. https://doi.org/10.1104/pp.103.032904
Dahleen LS, Manoharan M (2007) Recent advances in barley transformation. In Vitro Cell Dev Biol Plant 43:493-506. https://doi.org/10. 1007/s11627-007-9068-z

Delage E, Ruelland E, Guillas I, Zachowski A, Puyaubert J (2012) Arabidopsis type-III phosphatidylinositol 4-kinases $\beta 1$ and $\beta 2$ are upstream of the phospholipase $C$ pathway triggered by cold exposure. Plant Cell Physiol 53:565-576. https://doi.org/10.1093/pcp/ pcs011

Delage E, Puyaubert J, Zachowski A, Ruelland E (2013) Signal transduction pathways involving phosphatidylinositol 4-phosphate and phosphatidylinositol 4,5-bisphosphate: convergences and divergences among eukaryotic kingdoms. Prog Lipid Res 52:1-14. https://doi.org/10.1016/j.plipres.2012.08.003

Dennis ES, Dolferus R, Ellis M, Rahman M, Wu Y, Hoeren FU, Grover A, Ismond KP, Good AG, Peacock WJ (2000) Molecular strategies for improving waterlogging tolerance in plants. J Exp Bot 51:89-97. https://doi.org/10.1093/jexbot/51.342.89

Dhillon T, Morohashi K, Stockinger EJ (2017) CBF2A-CBF4B genomic region copy numbers alongside the circadian clock play key regulatory mechanisms driving expression of $F R-H 2 C B F$ s. Plant Mol Biol 94:333-347. https://doi.org/10.1007/s11103-017-0610-z

Doherty CJ, Van Buskirk HA, Myers SJ, Thomashow MF (2009) Roles for Arabidopsis CAMTA transcription factors in cold-regulated gene expression and freezing tolerance. Plant Cell 21:972-984. https://doi.org/10.1105/tpc. 108.063958

Filipecki M, Malepszy S (2006) Unintended consequences of plant transformation: a molecular insight. J Appl Genet 47:277-286. https:// doi.org/10.1007/BF03194637

Gierczik K, Novák A, Ahres M, Székely A, Soltész A, Boldizsár Á, Gulyás Z, Kalapos B, Monostori I, Kozma-Bognár L, Galiba G, Vágújfalvi A (2017) Circadian and light regulated expression of $C B F \mathrm{~s}$ and their upstream signalling genes in barley. Int $\mathrm{J} \mathrm{Mol} \mathrm{Sci}$ 18:1828. https://doi.org/10.3390/ijms18081828

Haak DC, Fukao T, Grene R, Hua Z, Ivanov R, Perrella G, Li S (2017) Multilevel regulation of abiotic stress responses in plants. Front Plant Sci 8:1564. https://doi.org/10.3389/fpls.2017.01564

Harwood WA, Bartlett JG, Alves SC et al (2009) Barley transformation using agrobacterium-mediated techniques. In: Huw DJ, Shewry PR (eds) Transgenic wheat, barley and oats. Methods in Molecular Biology ${ }^{\mathrm{TM}}$ (methods and protocols). Humana Press, pp 137-148

Hoagland DR, Arnon DI (1950) The water-culture method for growing plants without soil. Univ Calif Berkeley Coll Agric Circ 347:1-32

Horvath H, Jensen LG, Wong OT, Kohl E, Ullrich SE, Cochran J, Kannangara CG, von Wettstein D (2001) Stability of transgene expression, field performance and recombination breeding of transformed barley lines. Theor Appl Genet 102:1-11. https://doi.org/ $10.1007 / \mathrm{s} 001220051612$

Hou Q, Ufer G, Bartels D (2016) Lipid signalling in plant responses to abiotic stress. Plant Cell Environ 39:1029-1048. https://doi.org/10. 1111/pce. 12666

Kiełbowicz-Matuk A, Banachowicz E, Turska-Tarska A, Rey P, Rorat T (2016) Expression and characterization of a barley phosphatidylinositol transfer protein structurally homologous to the yeast Sec14p protein. Plant Sci 246:98-111. https://doi.org/10.1016/j. plantsci.2016.02.014

Ku Y-S, Koo NS-C, Li FW-Y, Li MW, Wang H, Tsai SN, Sun F, Lim BL, Ko WH, Lam HM (2013) GmSAL1 hydrolyzes inositol-1,4,5-trisphosphate and regulates stomatal closure in detached leaves and ion compartmentalization in plant cells. PLoS One 8:e78181. https:// doi.org/10.1371/journal.pone.0078181

Lata C, Yadav A, Prasad M (2011) Role of plant transcription factors in abiotic stress tolerance. In: Shanker A, Venkateswarlu B (eds) Abiotic stress response in plants - physiological, biochemical and genetic perspectives. InTech, pp 269-296 
Lichtenthaler HK, Buschmann C (2001) Chlorophylls and carotenoids: measurement and characterization by UV-VIS spectroscopy. In: Current protocols in food analytical chemistry. Wiley, pp F4.3.1-F4.3.8

Lindberg S, Kader A, Yemelyanov V (2012) Calcium signalling in plant cells under environmental stress. In: Ahmad P, Prasad MNV (eds) Environmental adaptations and stress tolerance of plants in the era of climate change. Springer-Verlag, New York, pp 325-360

Livak KJ, Schmittgen TD (2001) Analysis of relative gene expression data using real-time quantitative PCR and the $2^{-\Delta \Delta C T}$ method. Methods 25:402-408. https://doi.org/10.1006/meth.2001.1262

Luo M, Ding L-W, Ge Z-J, Wang ZY, Hu BL, Yang XB, Sun QY, Xu ZF (2012) The characterization of SaPIN2b, a plant trichome-localized proteinase inhibitor from Solanum americanum. Int J Mol Sci 13: 15162-15176. https://doi.org/10.3390/ijms131115162

Matzke AJM, Matzke MA (1998) Position effects and epigenetic silencing of plant transgenes. Curr Opin Plant Biol 1:142-148. https://doi. org/10.1016/S1369-5266(98)80016-2

Mickelbart MV, Hasegawa PM, Bailey-Serres J (2015) Genetic mechanisms of abiotic stress tolerance that translate to crop yield stability. Nat Rev Genet 16:237-251. https://doi.org/10.1038/nrg3901

Morran S, Eini O, Pyvovarenko T, Parent B, Singh R, Ismagul A, Eliby S, Shirley N, Langridge P, Lopato S (2011) Improvement of stress tolerance of wheat and barley by modulation of expression of DREB/CBF factors. Plant Biotechnol J 9:230-249. https://doi.org/ 10.1111/j.1467-7652.2010.00547.x

Ranty B, Aldon D, Cotelle V, Galaud JP, Thuleau P, Mazars C (2016) Calcium sensors as key hubs in plant responses to biotic and abiotic stresses. Front Plant Sci 7:327. https://doi.org/10.3389/fpls.2016.00327

Ricroch A, Clairand P, Harwood W (2017) Use of CRISPR systems in plant genome editing: toward new opportunities in agriculture. Emerging Top Life Sci 1:169-182

Ruelland E, Kravets V, Derevyanchuk M, Martinec J, Zachowski A, Pokotylo I (2015) Role of phospholipid signalling in plant environmental responses. Environ Exp Bot 114:129-143. https://doi.org/10. 1016/j.envexpbot.2014.08.009

Sallaud C, Meynard D, Van Boxtel J et al (2003) Highly efficient production and characterization of T-DNA plants for rice (Oryza sativa L.) functional genomics. Theor Appl Genet 106:1396-1408. https:// doi.org/10.1007/s00122-002-1184-x

Schonfeld MA, Johnson RC, Carver BF, Mornhinweg DW (1988) Water relations in winter wheat as drought resistance indicators. Crop Sci 28:526-531. https://doi.org/10.2135/ cropsci1988.0011183X002800030021x

Shen H, Zhong X, Zhao F, Wang Y, Yan B, Li Q, Chen G, Mao B, Wang J, Li Y, Xiao G, He Y, Xiao H, Li J, He Z (2015) Overexpression of receptor-like kinase ERECTA improves thermotolerance in rice and tomato. Nat Biotechnol 33:996-1003. https://doi.org/10.1038/nbt. 3321

Shu QY, Cui HR, Ye GY, Wu DX, Xia YW, Gao MW, Altosaar I (2002) Agronomic and morphological characterization of Agrobacteriumtransformed Bt rice plants. Euphytica 127:345-352. https://doi.org/ 10.1023/A: 1020358617257

Soltész A, Smedley M, Vashegyi I, Galiba G, Harwood W, Vágújfalvi A (2013) Transgenic barley lines prove the involvement of TaCBF14 and $T a C B F 15$ in the cold acclimation process and in frost tolerance. J Exp Bot 64:1849-1862. https://doi.org/10.1093/jxb/ert050

Stanley D, Rejzek M, Naested H, Smedley M, Otero S, Fahy B, Thorpe F, Nash RJ, Harwood W, Svensson B, Denyer K, Field RA, Smith AM (2011) The role of $\alpha$-glucosidase in germinating barley grains. Plant Physiol 155:932-943. https://doi.org/10.1104/pp.110.168328

Subbaiah CC, Bush DS, Sachs MM (1994) Elevation of cytosolic calcium precedes anoxic gene expression in maize suspension-cultured cells. Plant Cell 6:1747-1762. https://doi.org/10.1105/tpc.6.12.1747

Subbaiah CC, Bush DS, Sachs MM (1998) Mitochondrial contribution to the anoxic $\mathrm{Ca}^{2+}$ signal in maize suspension-cultured cells. Plant Physiol 118:759-771. https://doi.org/10.1104/pp.118.3.759

Sutka J (1981) Genetic studies of frost resistance in wheat. Theor Appl Genet 59:145-152. https://doi.org/10.1007/BF00264968

Terzi V, Tumino G, Pagani D, Rizza F, Ghizzoni R, Morcia C, Stanca A (2017) Barley developmental mutants: the high road to understand the cereal spike morphology. Diversity 9:21. https://doi.org/10. 3390/d9020021

Thomashow MF (1999) Plant cold acclimation: freezing tolerance genes and regulatory mechanisms. Annu Rev Plant Physiol Plant Mol Biol 50:571-599. https://doi.org/10.1146/annurev.arplant.50.1.571

Travella S, Ross SM, Harden J, Everett C, Snape JW, Harwood WA (2005) A comparison of transgenic barley lines produced by particle bombardment and Agrobacterium-mediated techniques. Plant Cell Rep 23:780-789. https://doi.org/10.1007/s00299-004-0892-x

Vyroubalová Š, Šmehilová M, Galuszka P, Ohnoutková L (2011) Genetic transformation of barley: limiting factors. Biol Plant 55:213-224. https://doi.org/10.1007/s10535-011-0032-8

Wan Y, Lemaux PG (1994) Generation of large numbers of independently transformed fertile barley plants. Plant Physiol 104:37-48. https:// doi.org/10.1104/pp.104.1.37

Wang E, Wang J, Zhu X, Hao W, Wang L, Li Q, Zhang L, He W, Lu B, Lin H, Ma H, Zhang G, He Z (2008) Control of rice grain-filling and yield by a gene with a potential signature of domestication. Nat Genet 40:1370-1374. https://doi.org/10.1038/ng.220

Wang X, Shan X, Xue C, Wu Y, Su S, Li S, Liu H, Jiang Y, Zhang Y, Yuan Y (2016) Isolation and functional characterization of a cold responsive phosphatidylinositol transfer-associated protein, ZmSEC14p, from maize (Zea may L.). Plant Cell Rep 35:16711686. https://doi.org/10.1007/s00299-016-1980-4

Xue H, Chen X, Li G (2007) Involvement of phospholipid signaling in plant growth and hormone effects. Curr Opin Plant Biol 10:483489. https://doi.org/10.1016/j.pbi.2007.07.003

Xue H-W, Chen X, Mei Y (2009) Function and regulation of phospholipid signalling in plants. Biochem J 421:145-156. https://doi.org/ 10.1042/BJ20090300

Zadoks JC, Chang TT, Konzak CF (1974) A decimal code for the growth stages of cereals. Weed Res 14:415-421. https://doi.org/10.1111/j. 1365-3180.1974.tb01084.x

Zhang JZ (2003) Overexpression analysis of plant transcription factors. Curr Opin Plant Biol 6:430-440. https://doi.org/10.1016/S13695266(03)00081-5

Publisher's Note Springer Nature remains neutral with regard to jurisdictional claims in published maps and institutional affiliations. 